\title{
A comparative study of metachromasy induced in Azure B by anionic polyelctrolytes
}

\author{
Nandini Ratnakar \\ Department of Chemistry, MITE, Moodabidri-574 226 (DK), Karnataka, India \\ Email address: \\ nandinifalnir@yahoo.com
}

To cite this article:

Nandini Ratnakar. A Comparative Study of Metachromasy Induced in Azure B by Anionic Polyelctrolytes. Science Journal of Chemistry. Special Issue: Polyelectrolytes \& Dyes. Vol. 2, No. 6-2, 2014, pp. 8-13. doi: 10.11648/j.sjc.s.2014020602.12

\begin{abstract}
The interaction of two cationic dyes, namely, Azure B (AB) with an anionic polyelectrolyte, namely, sodium heparinate (NaHep) has been investigated by Spectrophotometric method. The polymer induced metachromasy in the dyes resulting in the shift of the absorption maxima of the dyes towards shorter wavelengths. The stability of the complexes formed between Azure B and sodium alginate was found to be greater than that formed between Azure B and sodium carboxymethylcellulose.This fact was further confirmed by reversal studies using alcohols, urea surfactants and electrolytes.The interaction parametersrevealed that binding between Azure B and anionic poloyelectrolytes was mainly due to electrostaticinteraction.
\end{abstract}

Keywords: Cationic Dye, Metachromasy, Anionicpolyelectrolytes, Electrostatic Interaction, Aggregation

\section{Introduction}

Metachromasy is a well-known phenomenon in the case of dye-polymer interactions and is generally found in the case of aggregation of cationic dyes on anionicpolymers [14].Metachromasy is related to the interaction of cationic dyes with polyanions where a single individual compound is formed bythe interaction of the dye cation and the chromotrope polyanionic polymer.Several physiochemical parameters such as molecular weight of each repeating unit, stoichiometry of thedye-polymer complex, binding constant, and other related thermodynamic parameters like freeenergy, enthalpy, and entropy changes can be evaluated using polymer-dye interactions.Biological activity of macromolecules depends on its tertiary conformation. Conformation of the polyanions controls the induction of metachromasy of aqueous dye solution.Although there are several reports on metachromasy of various classes of acidic polysaccharides and different synthetic polyanions $[5,6]$. Cyanine dyes, which are cationic in nature, have widely been used to probe biological systems such as helical structure of DNA, tertiary conformation of bacterialpolysaccharides and other polymers. As these dye having high light absorptivity, they can be used as optical probes in studying membranes, micelles and other host systems [7-10]. Studies on polymersurfactant interaction in aqueous solution have been attracting widespread attention due to multiple practical uses in biology [11-14] .Such studies are also assumed to be important as themixed systems/aggregates can give rise to advanced functions that are unobtainable from singlecomponent [15].Several physicochemical properties of macromolecule - surfactants are quiterelevant in this context. Formulation procedures based on suitable mixture may have beenappealing applications [16-18] It has been noted that oppositely charged surfactant binds to polymer surfaces through both electrostatic and hydrophobic interaction [19]. Different techniques for their isolation and stability determination of metachromatic complexes have been reported in literature[20]. The phenomena of reversal of metachromasy by addition of urea, alcohol neutral electrolytes[21] and also by increasing the temperature of the system may be used to determine the stability ofthe metachromatic compounds.The nature of dye-polymer interaction in the metachromaticcomplex formation and also the conditions for the interaction between the cationic dye and theanionic site of the macromolecules has been studied by determining the thermodynamicparameters of the interaction [22].The interaction between polyelectrolytes and oppositely chargedsurfactants $[23,24]$ has been investigated due to its importance in both fundamental and appliedfields. [25] .Comprehensive studies of a variety of cationic surfactants with anionicpolyelectrolytes, have been reported [26-32].Cationic dyes that interacted with Heparin mostly fell 
in the Thiazine group such as MethyleneBlue [33-35]. Azure A [36, 37], Azure B [38,39]. Hence the objective of the present study is to compare the extent of metachromasy induced by sodium alginate and sodium carboxymethyl cellulose in the cationic dyes Azure B and to evaluate the thermodynamic parameters of interaction and to study the extent of reversal by using alcohols, urea, surfactants and electrolytes which is an indirectevidence for the stability of the metachromatic complex formed. The effect of dye structure onmetachromasy has also been discussed.

\section{Materials \& Methods}

\subsection{Apparatus}

The spectral measurements were carried out using Shimadzu UV-2500 Spectrophotometer using a $1 \mathrm{~cm}$ quartz cuvette.

\subsection{Reagents}

Azure B (AB) was obtained from (Hi Media, Germany) and used as received.

Sodiumcarboxymethyl cellulose(NaCMC)\& sodiumheparinate(NaHep) (Loba Chemie, India) were used without further purification; Methanol, (MeOH) ethanol(EtOH) and 2-Propanol (PrOH) (Merck, India) were distilled before use. Urea, sodium chloride and potassium chloride were obtained from (Merck, India). sodium laurylsulphate and sodiumdodecylbenzenesulphonate (Lobachemie, India) were obtained from (Loba Chemie, India) .

\section{Methods}

\subsection{Determination of Stoichiometry of Polymer-Dye Complex}

Increasing amounts of polymer solution $\left(0.0-\right.$ to $\left.5 \times 10^{-3} \mathrm{M}\right)$ were added to a fixed volume of dye solution $\left(0.5 \mathrm{ml}, 1 \times 10^{-3} \mathrm{M}\right)$ in case of Azure B in different sets of experiments and the total volume was made up to $10 \mathrm{ml}$ by adding distilled water in each case.The absorbances were measured at $547 \mathrm{~nm} \mathrm{n}$ case of AB-NaHep and at $562 \mathrm{~nm}$ in case of AB-NaCMC.

\subsection{Study of Reversal of Metachromasy Using Alcohols and Urea}

For measurements of the reversal of metachromasy, solutions containing polymer and dye in the ratio 2.0:1.0 were made containing different amount of alcohol.The total volume was maintained at $10 \mathrm{ml}$ in each case.The absorbances were measured at $645 \mathrm{~nm}$ and $545 \mathrm{~nm}$ in case of $\mathrm{AB}-\mathrm{NaHep}$ and at $645 \mathrm{~nm}$ and $562 \mathrm{~nm}$ in case of AB$\mathrm{NaCMC}$.Similarly, polymer-dye solutionscontaining different amounts of urea (1-8M) were made and the absorbances were measured at645 $\mathrm{nm}$ and at $547 \mathrm{~nm}$ in case of AB-NaHep complex and at $562 \mathrm{~nm}$ in case of $\mathrm{AB}-\mathrm{NaCMC}$ complex.

\subsection{Study of Reversal of Metachromasy Using Surfactants and Electrolytes}

For measurements of the reversal of metachromasy, solutions containing polymer and dye in the ratio 2.0:1.0 were made containing different amount of surfactants or $\left(1 \times 10^{-7} \mathrm{M}-1 \times 10^{-2} \mathrm{M}\right)$ were made in case of $\mathrm{AB}-\mathrm{NaHep}$ and $\left(1 \times 10^{-6} \mathrm{M}-0.1 \mathrm{M}\right)$ in case of $\mathrm{AB}-\mathrm{NaCMC}$ The total volume wasmaintained at $10 \mathrm{ml}$ in each case.The absorbances were measured at $645 \mathrm{~nm}$ and $547 \mathrm{~nm}$ in caseof AB-NaHepand at $645 \mathrm{~nm}$ and $562 \mathrm{~nm}$ in case of AB-NaCMC.Similarly, polymer-dye solutions containing different amounts of electrolytes $\left(1 \times 10^{-6} \mathrm{M}-0.1 \mathrm{M}\right)$ in case of $\mathrm{AB}-\mathrm{NaAlg}$ and $\left(1 \times 10^{-}\right.$ $\left.{ }^{7} \mathrm{M}-1 \times 10^{-2} \mathrm{M}\right)$ in case $\mathrm{AB}-\mathrm{NaCMC}$ were made and the absorbances were measured at $645 \mathrm{~nm}$ and at $547 \mathrm{~nm}$ in case of AB-NaHep complex and at $645 \mathrm{~nm}$ and at $562 \mathrm{~nm}$ in case of AB-NaCMC complex. A plot of absorbance at $645 \mathrm{~nm}$ Vs molar concentration of surfactants or electrolytes was made todetermine the concentration of surfactants and electrolytes needed for complete reversal ofmetachromasy.

\subsection{Determination of Thermodynamic Parameters}

The thermodynamic parameters were determined by measuring the absorbances of the pure dye solution at the respective monomeric band and metachromatic band in the temperature range (360C-540C). The above experiments were repeated in presence of the polymers at various polymer-dye ratios $(2,5,8$ and 10).

\section{Results \& Discussion}

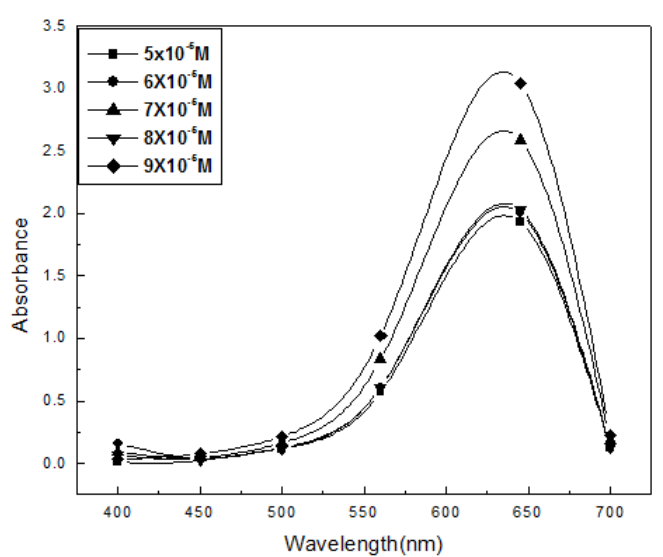

Figure 1. Absorption spectrum of $A B$ at various concentrations

The absorption spectra of Azure B shows an absorption maximum at $645 \mathrm{~nm}$ in case of Azure B indicating the presence of a monomeric dye species in the concentration range studied. On adding increasing amounts ofpolymer solution the absorption maxima shifts to $547 \mathrm{~nm}$ in case of $\mathrm{AB}-\mathrm{NaHep}$ and at $562 \mathrm{~nm}$ incase of AB-NaCMC complex. The blue shifted band is attributed to the stacking of the dyemolecules on the polymer backbone and this reflects high degree of co-operativity in binding [40].Appearance of multiple banded spectra proposed that the polymer might have a random coilstructure in solution. Whereas at higher 
concentration of the polymer almost a single bandedspectrum was observed due to possible change from random coil to helical form [41].The absorption spectra at various P/D ratios are shown in (Fig.1 and Fig.2) respectively.

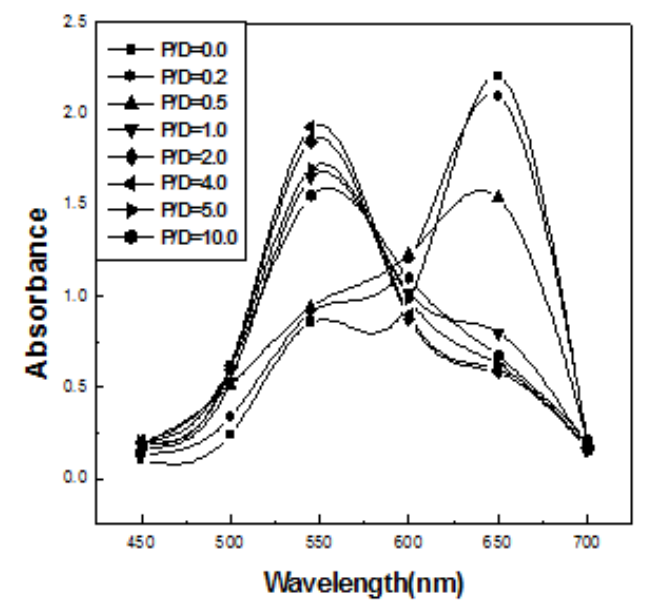

Figure 2. Absorption spectrum of AB-NaHep at various P/D ratios

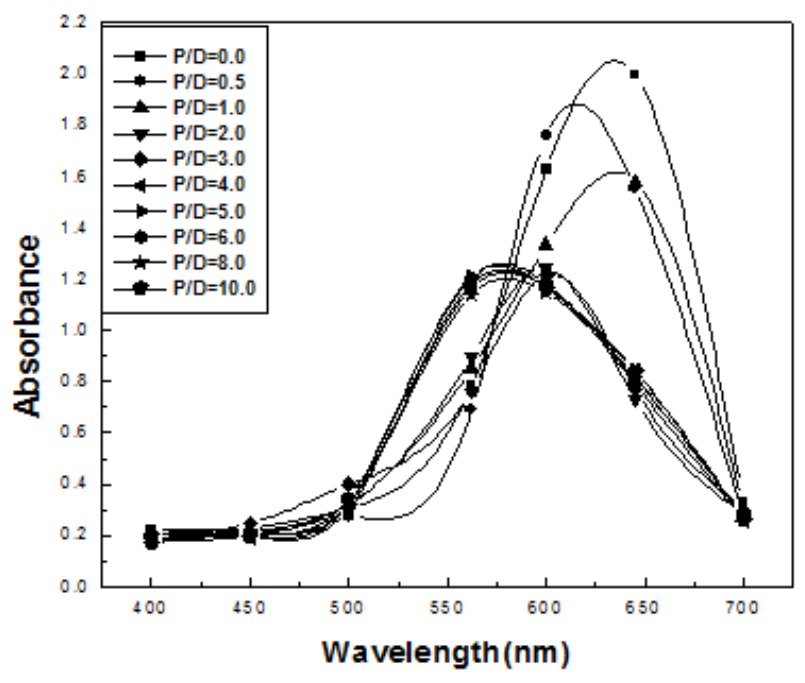

Figure 3. Absorption spectra of AB-NaCMCsystem at various $P / D$ ratio

\subsection{Determination of Stoichiometry}

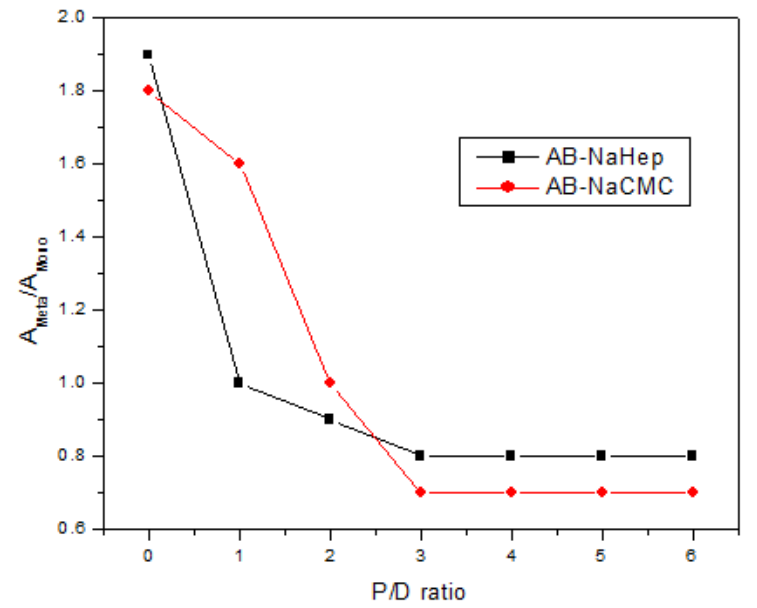

Figure 4. Stoichiometry of AB-NaHep \& AB-NaCMC complex
To determine the stoichiometry of the polymer-dye complex, a plot of $\mathrm{A}_{547} / \mathrm{A}_{645}$ versus the polymer/dye ratio was made for $\mathrm{AB}-\mathrm{NaHep}$ system.A similar procedure was repeated with $\mathrm{AB}-\mathrm{NaCMC}$ complex also. The stoichiometry of $\mathrm{AB}-\mathrm{Na} \mathrm{CMC}$ complex was found 2:1 which indicates that the binding is at alternate anionic sites. This indicates that every potential anionic site of thepolyanion was associated with the dye cation and aggregation of such dye molecules wasexpected to lead to the formation of a card pack stacking of the individual monomers on thesurface of the polyanion so that the allowed transition produces a blue-shifted metachromasy [42].The results were in good agreement with the reported values for interaction of similar dyes withpolyanions[43].While in case of AB-NaAlg complex the stoichiometry is $1: 1$ and the binding is at adjacent anionic sites.This indicates that there is lesser overcrowding and more aggregation of the bound dyes on the polymer chain in the latter case than in the former case. Similar resultswere reported in case of binding of Pinacyanol chloride on poly(methacrylicacid) \&poly(styrenesulfonate) systems [44].The stoichiometry results are obtained by plotting $\mathrm{A}_{645} / \mathrm{A}_{547}$ or $\mathrm{A}_{645} / \mathrm{A}_{562} \mathrm{Vs} \mathrm{P} / \mathrm{D}$ ratio in each case.The results are shown in (Fig. 4).

\subsection{Reversal of Metachromasy Using Alcohols and Urea}

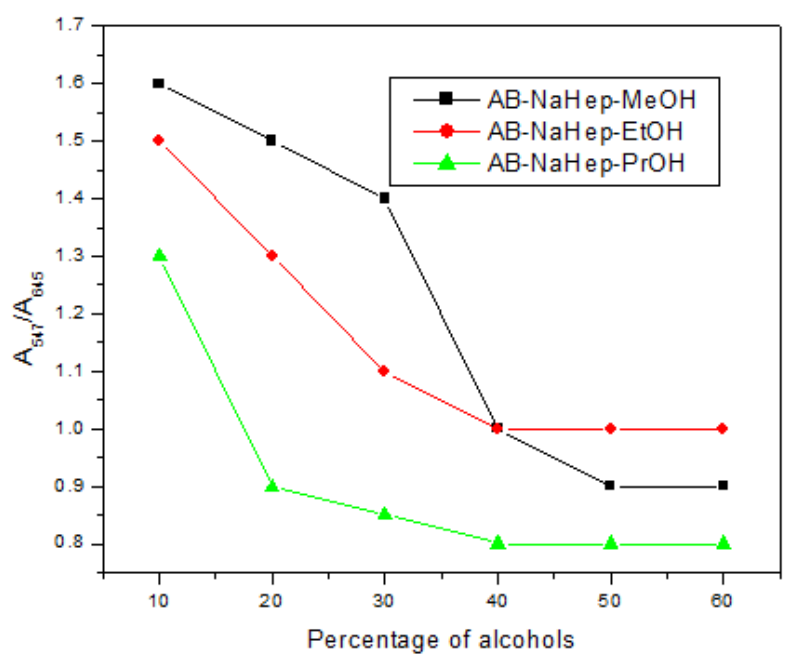

Figure 5. Reversal of metachromasy on addition of alcohols(AB-NaHep)

The metachromatic effect is presumably due to the association of the dye molecules on binding with the polyanion which may involve both electrostatic and hydrophobic interactions. The destruction of metachromatic effect may occur on addition of low molecular weight electrolytes, alcohols or urea.The destruction of metachromasy by alcohol and urea is attributed to the involvement of hydrophobic bonding has already been established [45-49].The efficiency of alcohols in disrupting metachromasy was found to be in the order methanol<ethanol< 2 - propanol, indicating that reversal becomes quicker with increasing hydrophobic character of the alcohols. The above facts are further confirmed in the present system . On addition of increasing amount of alcohol 
to the polymer/dye system at $\mathrm{P} / \mathrm{D}=2.0$, the original monomeric band of dye species is gradually restored. The efficiency of the alcohols, namely methanol, ethanol and 2propanol, on destruction of metachromasy were studied. In case of AB-NaHepsystem $60 \%$ methanol, $50 \%$ ethanol, $40 \%$ 2- Propanol were sufficient to reverse metachromasy $40 \%$ methanol, $30 \%$ ethanol, $20 \%$ 2- Propanol were required to reverse metachromasy in $\mathrm{AB}-\mathrm{NaCMC}$ system. From the plot of A547/A645 or A562/A645 (Fig.5and Fig6) against the percentage of alcohols or molar concentration of urea, the percentage of alcohols or molar concentration ofurea, needed for complete reversal has been determined.The concentration of urea to reversemetachromasy is found to be as high as $4 \mathrm{M}$ in $\mathrm{AB}-\mathrm{NaHep}$ system and $3 \mathrm{M}$ in case of $\mathrm{AB}-\mathrm{NaCMC}$ system (Fig7)This indicates that the metachromatic complex formed between $\mathrm{AB}-\mathrm{Na}$ Algis more stable than that between $\mathrm{AB}$ $\mathrm{NaCMC}$ complexes.Similar reports are available inliterature for reversal of metachromasy in anionic polyelectrolyte/cationic systems by addition of alcohols or urea $[50-51\}$.

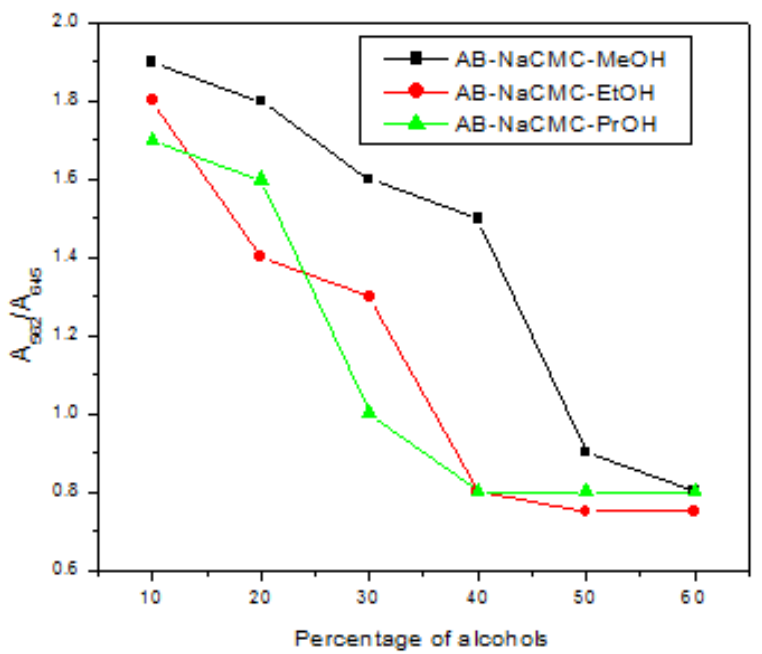

Figure 6. Reversal of metachromasy on addition of alcohols(AB-NaCMC)

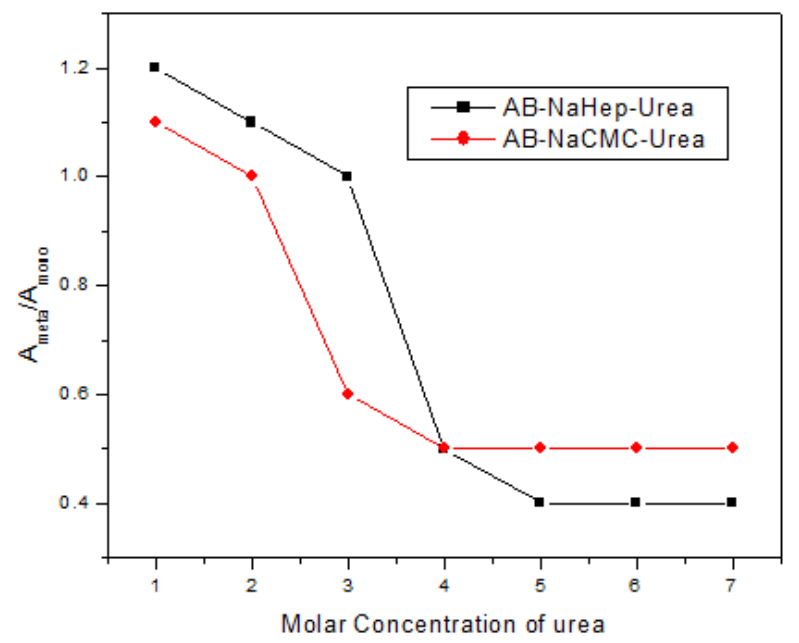

Figure 7. Reversal of metachromasy on addition of Urea in AB-NaHep\&ABNaCMC systems

\subsection{Reversal of Metachromasy Using Surfactants}

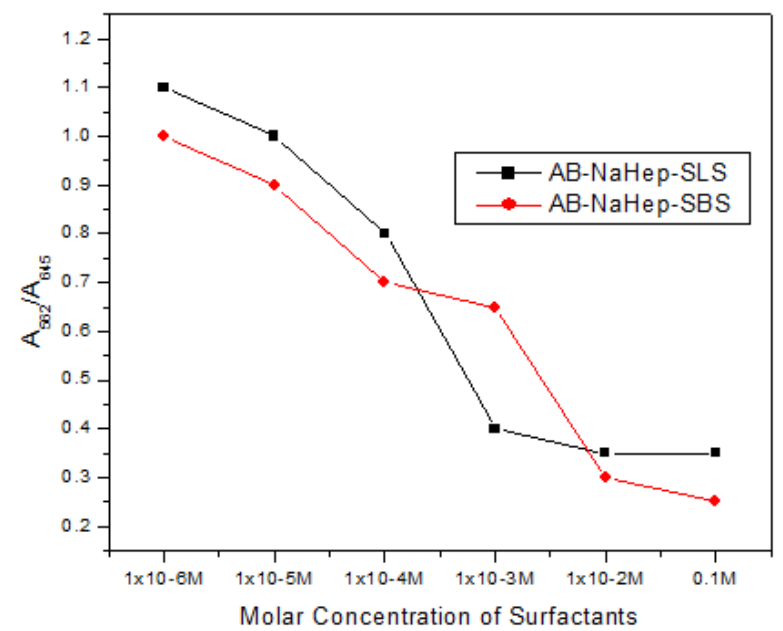

Figure 8. Reversal of metachromasy on addition of surfactants-ABNaHep

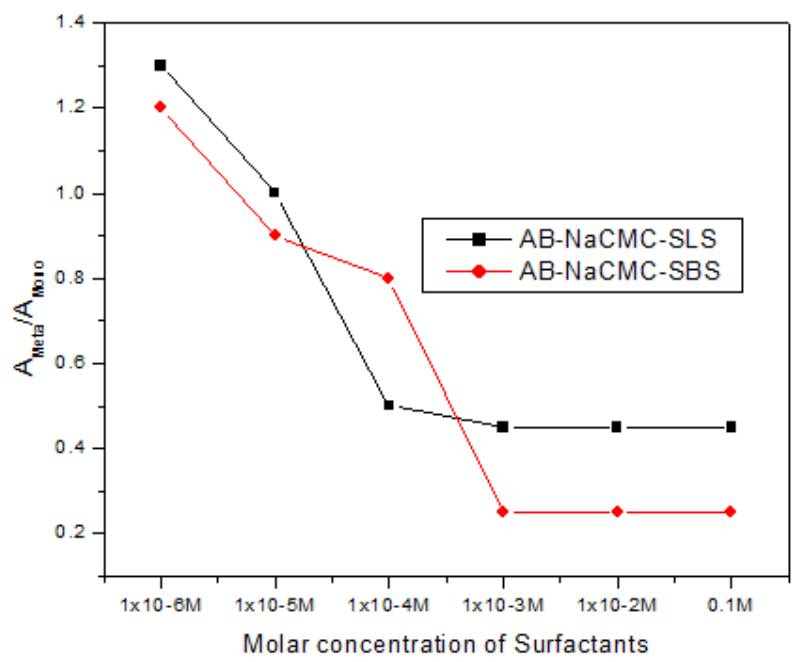

Figure 9. Reversal of metachromasy on addition of surfactants(AB-NaCMC

The strength and nature of interaction between water soluble polyelectrolytes and oppositely charged surfactants depend on the characteristic features of both the polyelectrolytes and the surfactants.The charge density, flexibility of the polyelectrolyte and the hydrophobicity of the non-polar part and the bulkiness of the polar part also play a vital role in the case ofpolysaccharide-surfactant interaction [52]. On adding increasing amounts of sodium laurylsulphate and sodium dodecylbenzenesulphonate to ABNaHep complex the molar concentrations ofSodium laurylsulphate and Sodium dodecylbenzenesulphonate needed to cause reversal wasfound to be $1 \times 10^{-3} \mathrm{M}$ and $1 \times 10^{-}$ ${ }^{2} \mathrm{M}$ in case of $\mathrm{AB}-\mathrm{NaHep}$ and $1 \times 10^{-3} \mathrm{M}$ and $1 \times 10^{3} \mathrm{M}$ in case of $\mathrm{AB}-\mathrm{NaCMC}$ system.These results agree with those reported earlier in literature $[53,54]$.Thus the addition of surfactants causes the production of micelles. Thus the surfactant molecules interacted with the polymer by replacing the cationic dye.The release of dye molecules from the dyepolymer complex in presence of cationic surfactants revealed that surfactants interacted electrostatically [55,56 ]with the 
anionic site of the polymer and thus the dye becomes free.The ease of reversal of metachromasy can be correlated with its chain length thus the binding between oppositely charged polymer surfactant is primarily by electrostatic forces which is reinforced byhydrophobic forces.From the plot of absorbance at $\mathrm{A}_{\text {meta }} / \mathrm{A}_{\text {mono }}$ in case of Azure $\mathrm{B}$ against molar concentration of surfactants, the molarconcentration of surfactants needed for complete reversal of metachromasy has been determined.The results are shown in (Fig. 8 and Fig.9)

The interaction constant $\mathrm{K}_{\mathrm{C}}$ for the complex formation between $\mathrm{AB}$ and NaHep and $\mathrm{AB}-\mathrm{NaCMC}$ was determined by absorbance measurements at the metachromatic band at four differenttemperatures taking different sets of solutions containing varying amounts of polymer $\left(\mathrm{C}_{\mathrm{S}}\right)$ in afixed volume of the dye solution $\left(\mathrm{C}_{\mathrm{D}}\right)$. The value of $\mathrm{Kc}$ was obtained from the slope andintercept of the plot of $\mathrm{C}_{\mathrm{D}} \mathrm{C}_{\mathrm{S}} /(\mathrm{A}-$ $\mathrm{A}_{\mathrm{O}}$ ) against $\mathrm{Cs}$ shown in Fig.10 \&Fig.11.In each case the thermodynamic parameters of interaction, namely $\Delta \mathrm{H}, \Delta \mathrm{G}$ and $\Delta \mathrm{S}$ were also calculated.The results are given in Table 1. $\left(C_{S}\right)$ in afixed volume of the dye solution $\left(C_{D}\right)$. The value of $\mathrm{Kc}$ was obtained from the slope

Table 1. Effect of temperature on AB-NaHep\&AB-NaCMC system

\begin{tabular}{|c|c|c|c|c|c|}
\hline System & $\begin{array}{l}\text { Temp } \\
(\mathbf{K})\end{array}$ & $\begin{array}{l}\mathrm{K}_{\mathrm{C}} \\
\left(\mathrm{dm}^{3} \mathrm{~mol}^{-1}\right)\end{array}$ & $\begin{array}{l}\Delta \mathrm{G} \\
\left(\mathrm{kJ} . \mathrm{mol}^{-1}\right)\end{array}$ & $\begin{array}{l}\Delta \mathrm{H} \\
\left(\mathrm{kJ} . \mathrm{mol}^{-1}\right)\end{array}$ & 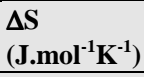 \\
\hline \multirow{4}{*}{$\begin{array}{l}\text { AB- } \\
\text { NaHep }\end{array}$} & 309 & 10783 & -23.8 & \multirow{4}{*}{-18.0} & \multirow{4}{*}{-28.3} \\
\hline & 315 & 8095 & -23.7 & & \\
\hline & 321 & 7628 & -23.5 & & \\
\hline & 327 & 6324 & -23.4 & & \\
\hline \multirow{4}{*}{$\begin{array}{l}\mathrm{AB}- \\
\mathrm{NaCMC}\end{array}$} & 309 & 9856 & -23.8 & \multirow{4}{*}{-26.3} & \multirow{4}{*}{-33.3} \\
\hline & 315 & 8176 & -24.0 & & \\
\hline & 321 & 7654 & -24.2 & & \\
\hline & 327 & 5432 & -24.3 & & \\
\hline
\end{tabular}

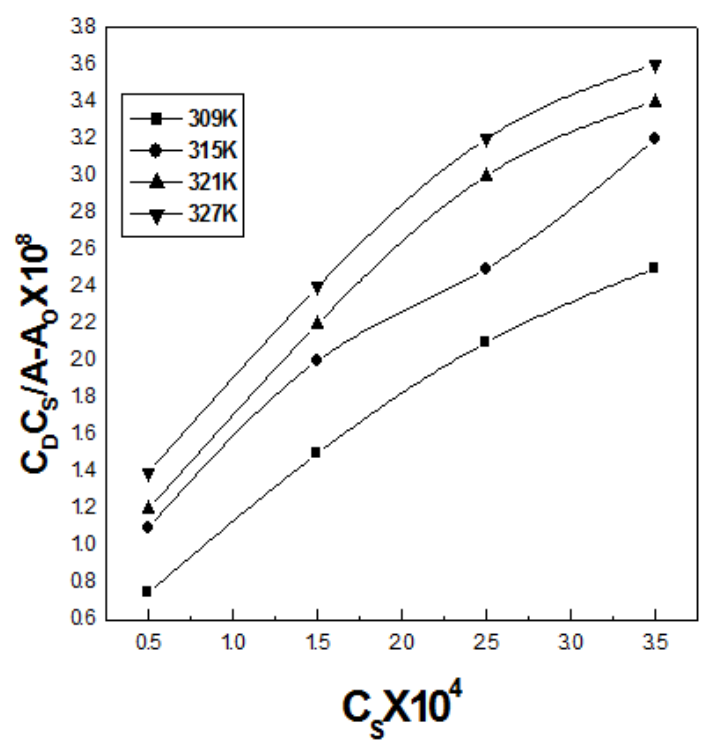

Figure 10. Effect of temperature on AB-NaHep system

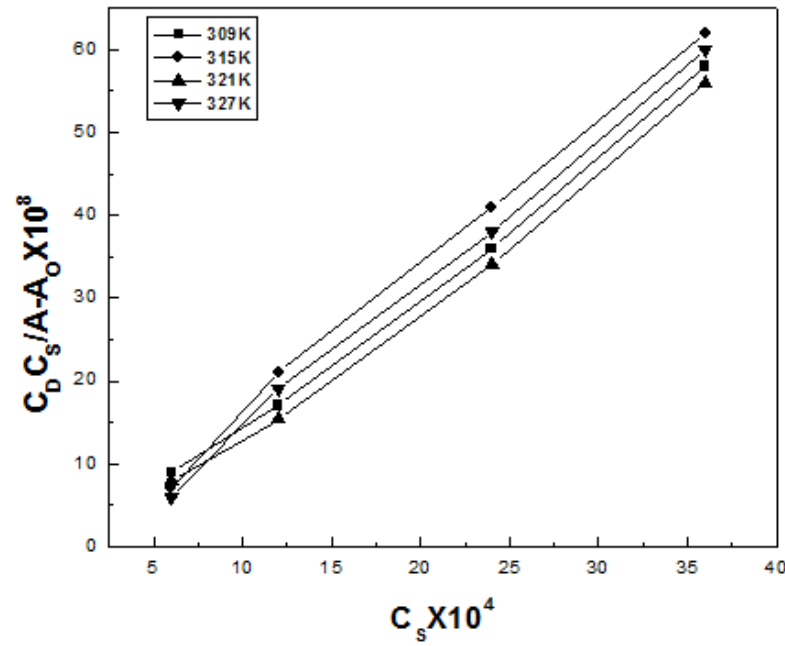

Figure 11. Effect of temperature on AB-NaCMC system

\section{Conclusion}

The polymers sodium heparinate and sodium carboxymethyl cellulose induced metachromasy in the dye Azure B .The monomeric band occurs at $645 \mathrm{~nm}$ while the metachromatic bandoccurred at $547 \mathrm{~nm}$ in the case of ABNaHep $(98 \mathrm{~nm})$ and at $562 \mathrm{~nm}$ in the case of ABNaCMC. $(83 \mathrm{~nm})$. These results are further confirmed by the reversal studies using alcohols, urea, electrolytes and surfactants. The thermodynamic parameters further confirm the above fact. It is thus evidentfrom the above studies that both electrostatic and non-ionic forces contribute towards the bindingprocess. Based on the results it can be concluded that the Azure B is more effective in inducing metachromasy in sodium heparinate than in sodium carboxymethyl cellulose..Cooperativity in binding is observed to occur due to neighbour interactions among the bound dye molecules at lower P/Dratios leading to stacking. The stacking tendency is enhanced by the easy availability and closeproximity of the charged sites.

\section{References}

[1] A Mitra, R. K Nath,, SBiswas., A. K., Chakraborty, A. K., Panda Mitra A. , J. Photochrem. Photobiol, A: Chem, vol.111, 1997, pp 157.

[2] A.Mitra, A.K.Chakraborty, J.Photochem.Photobiol.A:Chem., vol.178,2006, pp198.

[3] R.W Horbin., Biochemie.Biochem., vol.77, 2002, pp 3.

[4] Bergeron J. A., M. J Singer,. Biophys. Biochem. Cytol. vol.4,1958, pp.433.

[5] M. K. Pal , B. K. Ghosh, Makromol. Chem. vol. 181, 1980, pp1459.

[6] Norden B., Kubista M., in : B.Samori, E.W.Thulstrup (Eds.), Polarized Spectroscopy of ordered systems, vol.242,Kulwer Academic Publisher, Dordrecht, Holland, 1988.

[7] Sabate R., EsterlichJ., J.Phys.ChemB, vol.107,2003, pp.4137. 
[8] von Berlepsch H., Kirstein S., Bottcher, C, Langmuir, vol.18,2002,pp.769.

[9] Sabate R., Gallardo M., De la Maza A., J.Esterlich, Langmuir,vol.17,2001, pp.6433.

[10] Berret J.F., Cristobal G.,Hervel P., Oberdisse J.,Grillo I., vol.E9, Eur.Phys J 2002, pp.301.

[11] Meszaos R., Varga, I.,Gilanyi T.,J.Phys.Chem.B vol.117, 2005, pp. 13538 .

[12] Monteux C . ,WilliamsC.E., Meunier J., Anthony O., BergeronV., Langmuir Vol.20,2004,pp. 57.

[13] Honda C., Kamizono H.,.Matsumoto K., Endo K., J.Colloid Interface Sci vol.278.2004, , pp.310.

[14] MoulikS.P., GuptaS,.DasA.R., Makromol.Chem,vol.181, 1980,pp. 1459.

[15] Lee J ., Moroi Y,,J.Colloid Interface Sci. 2vol.273,2004, pp.645.

[16] Mesa C.L., J.Colloid Interface Sci . vol.286,2005, pp.148.

[17] Konradi R.,Ruhe J., Macromolecules vol.38,2005, pp.6140.

[18] VilletiM., BorsaliA., Crespo R.,SoldiV.,Fukada K., Macromol.Chem.Phys. vol.205,2004, pp.907.

[19] Fundin J,,Hansson P.,Brown W., Lidegran I.,Macromolecules vo.30, 1997, pp.1118.

[20] Mitra A., Nath A. R., and ChakrabortyA.K.,Colloid Polym Sci. , vol.271,1993, pp.1042.

[21] Panda A.K., Chakraborty A.K., J.Colloid Interface Sci. vol.203,1998, pp.260.

[22] Chakraborty, A.K,.Nath, R.K, Spectrochim Acta vol.45A,1989, pp.981.

[23] Jain N. ,Trabelsi S., Guillot S.,Meloughlin D. ,Langevin D., Leteiller P., Turmine, M., Langmuir, vol..20,2004, pp.8496.

[24] Bakshi M.S., Varga I., GilanyiT.,J.Phys.Chem.B,vol. 109,2005 , pp. 13538 .

[25] Balomenou L., and Bokias G., Langmuir, vol. 21,2005, pp.9038.

[26] Bakshi M.S., and Sachar S.,Colloid Polym.Sci. vol.283,2005,pp.671.

[27] Romani A.P., Gehlen M.H., Itri R., Langmuir, vol.21,2005, pp.127.

[28] Wang C., Tam K.C., Langmuir, vol.18,2002, pp. 6484.

[29] Sjogren H .,Ericsson C.A., Evenas J.,Ulvenlund S .,Biophys J., vol.89,2005, pp.4219.

[30] Zhu D.M., EvansR.K., Langmuir, 2006, 22 ,pp.3735.

[31] Chatterjee A.,Moulik S.P., Majhi P.R., and Sanyal S.K., Biophys Chem.vol.98,,2002,98, pp.313.

[32] Mata J., Patel J., Jain N.,Ghosh G.,Bahadu, P., J.Colloid Interface Sci. 2006, 297 , pp.797.
[33] Jiao Q.C., Liu Q .,Sun C., and He H ., Talanta, vol.1095,1999, , pp.48.

[34] Liu Q.,and Jiao Q.C .,Spectrosc.Lett., vol.31,1998, pp.913.

[35] Jiao Q.C. ,and Liu Q.,Spectrochim. Acta, 1vol.55A,999, pp.1667.

[36] Jiao Q.C and Liu Q., Anal.Lett. vol..31,1998, pp.1311.

[37] Jiao Q.C. , and Liu Q, Spectrosc.Lett.vol.31, 1998, pp.1353.

[38] Hugglin D., Seiffert, A.,Zimmerman, W,Histochemistry, vol.86,1986, pp.71.

[39] Mitra A ., Nath R.K .,and. Chakraborty A.K., Colloid Polym. Sci., vol.271,1993, pp.1042.

[40] Basu. S. , Gupta A.K. ,and Rohatgi-Mukherjee K. K, J.Indian Chem. Soc.1vol.59,982, pp.578 .

[41] Pal M.K., SchubertM.J. Histochem Cytoche., vol.9,1961,pp. 673.

[42] Pal M.K,,and Ghosh B.K., Macromol.Chem, vol.181,1980,pp. 1459.

[43] Pal M.K and Ghosh B.K., Macromol.Chem. vol.180,1979, pp.959.

[44] Pal M.K and Schubert M .,J.Phys.Chem., vol.17,1963,pp.182.

[45] Frank. H.S., and.Evans M.W .,J.Chem.Phys. vol.17,1945, pp.507 .

[46] Kauzmann W.,Advan.Protein.Chem.vol.14, 1959, pp1.

[47] Bruning and Holtzer A., J.Am.Chem Soc.,vol.83,1961, pp. 4865 .

[48] WhitneyP.L., and Tanford C., J.Biol.Chem vol.237,1962, pp. 1735 .

[49] Mukerjee P.,and Ray A. ,J.Phys.Chem. vol.67,1963, pp.190.

[50] Frank H.S. and Quist A.S., J.Chem.Phys.,1vol.34,961, pp.604.

[51] Rabinowitch E., Epstein., L.F J. Am. Chem. Soc., vol.63, 1941,pp.69.

[52] Romani A.P., Gehlen M.H. and. Itri R., Langmuir, vol.21,2005, pp. 127.

[53] Levine A., Schubert M., J.Am.Chem.Soc., vol.74,1958, pp.5702.

[54] Dasgupta S., Nath R.K. ,Biswas S., Hossain J., Mitra A.,and Panda A.K. ,Colloids Surf A: Physicochem Eng.Aspects, vol.302,2007, pp.17.

[55] RoseNJ; DragoRS; Journal of American Chemical Society, 1vol.81,959, pp.6138.

[56] Nandini R, Vishalakshi B,e-journal of chemistry, vol.8,2011, pp.S253.

[57] Nandini R, Vishalakshi B,spectrochimica acta Part A, vol.9,2009, pp.1025 